\title{
Convergence or Divergence? Chinese Novice EFL Teachers' Beliefs about Postmethod and Teaching Practices
}

\author{
Zhengping Zeng ${ }^{1}$ \\ ${ }^{1}$ School of Foreign Languages, Leshan Normal University, Leshan, China \\ Correspondence: Zhengping Zeng, School of Foreign Languages, Leshan Normal University, Leshan, Sichuan, \\ China. Tel: 86-158-8435-4565. E-mail: bzzhp888@126.com
}

Received: July 12, 2012 Accepted: July 24, 2012 Online Published: August 16, 2012

doi:10.5539/elt.v5n10p64 URL: http://dx.doi.org/10.5539/elt.v5n10p64

This research is financed by the Research Projects of Leshan Normal University (No.S1230).

\begin{abstract}
Recently, there have been numerous researches focusing on postmethod. Generally, the researches can be divided into three perspectives: a new look at method, theoretical exploration of postmethod, implication for teacher education. Obviously, language researchers tend to focus on the theoretical review on postmethod ignoring the actual use of postmethod in practice. The study was conducted to explore Chinese novice EFL teachers' conceptions and implement of postmethod. The data were collected through lesson observations and interviews. The results reveal that the novice teachers lack the knowledge of postmethod, that they are greatly influenced by examination-oriented education, and that there is a discrepancy between teaching behaviors and teacher beliefs.
\end{abstract}

Keywords: EFL teaching, teacher professional development, teacher belief, postmethod, teaching practice, teaching strategy

\section{Introduction}

\subsection{Recent Researches on Postmethod}

Recently, there have been numerous researches on postmethod. Stern (1999), a Canadian educational expert, is the earliest one to discuss the idea of postmethod by analyzing three dimensions: "intralingual-crosslingual", "analytical-experiential" and "explicit-implicit". Kumaravadivelu constructed postmethod theory that includes postmethod condition, postmethod pedagogy and the framework of macrostrategies (1994; 2001; 2003; 2006). After Kumaravadivelu put forward postmethod theory, many experts and scholars in the field of EFL/ESL teaching responded actively. Briefly, the responses can be divided into 3 categories. The first is taking a new look at method. Brown (2002) explored English language teaching in postmethod era and held the view that method was dead. Liu Dilin (1995) from Oklahoma City University raised his viewpoint of "addition to method" as his response to Kumaravadivelu's viewpoint of "alternative to method". Bell (2003) discussed whether method and postmethod are really incompatible. Second is further explored the postmethod theoretically. Richard and Rodgers (2001) discussed postmethod from the aspects of the top-down criticism, roles of contextual factors, beyond approaches and methods. Adamson (2004) proposed his own views on postmethod theory. According to his opinions, teachers are teaching practitioners, teaching researchers and theory constructors. Such beliefs regarding postmethod still exist in some of Allwright's explorations (1994) such as "teachers as researchers: unmixing the metaphor", and "rethinking practitioner research in language teaching". The last category is implication for teacher education. Arikan (2006) from Pennsylvania State University explored postmethod condition and its implications for English language teacher. Based on the English language teaching in Iran, Broudy (2008) did a descriptive exploratory survey "A paradigm shift away from method-wise teaching to strategy-wise teaching: reconstructive strategy versus communicative strategy".

Admittedly, there lacks the researches on real language teachers' implementation of postmethod. Language researchers tend to focus on the theoretical review on postmethod ignoring the actual use of postmethod in practice. Consequently, the field of language teaching has faced several important issues towards postmethod: (1) How much do novice EFL teachers know about postmethod? (2) How do novice EFL teachers implement postmethod in practice? (3) How to help novice EFL teachers implement postmethod in teacher education? 


\subsection{Necessity of the Research}

This study, exploring Chinese novice EFL teachers' beliefs about postmethod through a case, is not only the trend of research on language teaching methodology but also the response to the practical problems in junior schools' EFL classrooms. By means of deeply understanding how the novice EFL teachers adopt methods in their practical classrooms and what beliefs about postmethod they have, this paper is intentionally planned to draw the EFL teachers' attention and retrospect to their existing teaching methods so as to help them initially think over the ways they use teaching methods. To some extent, some thoughts for EFL teaching are supposed to be provided.

\section{Theoretical Framework of the Study}

At the end of $1980 \mathrm{~s}$, with the criticism on the concept of method itself in the field of language teaching, Kumaravadivelu (1994) first proposes the concept of postmethod which signifies a search for an alternative to method rather than an alternative method. Postmethod is not one real teaching method but contains three hierarchies: postmethod condition, postmethod pedagogy and macrostrategic framework.

\subsection{Postmethod Condition}

Postmethod condition includes three interrelated attributes. It signifies a search for "alternative methods" to "alternative to methods", teacher autonomy, and principled pragmatism. Principled pragmatism means that attitudes and actions are influenced by practical day-to-day consequences (Wenger, 2007).

\subsection{Postmethod Pedagogy}

With a solid foundation of postmethod condition, postmethod pedagogy emerges, and it is a three-dimensional system composed of parameters of particularity, practicality and possibility. The pedagogy of particularity refers to language pedagogy which must be sensitive to a particular group of teachers teaching a particular group of learners pursing a particular set of goals within a particular institutional context embedded in a particular socio-cultural milieu. The pedagogy of practicality pertains to a much large issue that has a direct impact on the practice of classroom teaching, namely, the relationship between theory and practice. The pedagogy of possibility is regarded with students' and teachers' subject positions - class, gender, race, ethnicity, and the experiences that they bring to the pedagogical settings.

\subsection{Macrostrategies Framework}

For carrying out the features of postmethod pedagogy, a coherent framework which includes ten macro-strategies which are derived from theoretical, empirical, and pedagogical knowledge related to L2 learning/teaching has been constructed. (1) Maximizing Learning Opportunities (MLO), (2) Facilitating Negotiated Interaction (FNI), (3) Minimizing Perceptual Mismatches (MPM), (4) Activating Intuitive Heuristics (AIH), (5) Fostering Language Awareness (FLA), (6) Contextualizing Linguistic Input (CLI), (7) Integrating Language Skills (ILS), (8) Promoting Learner Autonomy (PLA), (9) Raising Cultural Consciousness (RCC), (10) Ensuring Social Relevance (ESR).

\section{The Study}

\subsection{Research Background}

Two novice EFL teachers were randomly selected from two municipal key schools respectively in Chengdu, Sichuan Province, China. The two schools have a heterogeneous make-up that reflects the composition of most common junior middle schools in China. The two subjects are female junior English teachers, undergraduates. One has two years' teaching experience; the other has three years' teaching experience. The two participating novice teachers in this study have been assigned pseudonyms, Teacher A and Teacher B.

\subsection{Data Collection}

A qualitative research case-study approach was adopted in this study to investigate the novice EFL teachers' beliefs about postmethod and the ways they use teaching methods in postmethod era. Specifically, this is aiming at answering the following three questions: (1) How much do novice EFL teachers know about postmethod? (2) How do novice EFL teachers implement postmethod in practice? (3) How to help novice EFL teachers implement postmethod in teacher education?

Four classroom observations which include listening, speaking, reading, and writing were videotaped for each participant. Post-class interview took place directly after videotaping two subjects' classroom teaching behaviors regarding postmethod which can be used to generate some enquiries during the interviews. Each interview lasted forty to fifty minutes and the statements were recorded and fully transcribed afterwards. 


\subsection{Data Analysis}

Data from the teachers' interviews and the classroom observation were compared for evidence of convergence or divergence between the teachers' stated beliefs about postmethod and their actual practices (Cohen and Manion, 1989). The data were transcribed only for examples on two subjects' actual practice of macro-strategies. The data was analyzed for classroom practices (use of teaching strategies), teacher beliefs concerning postmethod, teaching practices and teacher beliefs. To facilitate data analysis, a code book for the classroom observation was developed specifying the variable names, description and examples.

\subsection{Findings and Discussion}

Generally, the findings show that the two novice teachers lack the beliefs within the theory of postmethod pedagogy. They do not agree the idea "theorizing from practice". Greatly influenced by examination-oriented education, both teachers almost use the same method in different types of lessons, and they are always busy in explaining the language points, asking students questions and offering answers. All serve the examinations. In addition, there is a large discrepancy between teacher beliefs and their teaching practices.

\subsubsection{Classroom Practices: Use of Macrostrategies}

This section reports the teaching strategies from the perspective of the macrostrategic framework. MLO, FNI, MPM, AIH, FLA, CLI, ILS, PLA, RCC, and ESR are the acronyms of the ten macro-strategies raised by Kumaravadivelu. The observed lessons of both teachers are interpreted as being teacher-centered. They are always busy in passing on the knowledge to the students in the class. The classroom practices reflect some teaching strategies the teachers adopted consciously or unconsciously in their classrooms.

Derived from the classroom behaviors, MLO, FNI, CLI and PLA are mainly adopted by the two teachers (See Table 1). In fact, there is a difference between the macrostrategy implemented by the teachers and the macrostrategy raised by Kumaravadivelu. In this section, the author only shows whether the teachers use some of the macrostrategies instead of differentiating the degrees of the similarity.

Table 1. Summary of teachers' practices

\begin{tabular}{lllllllllll}
\hline & MLO & FNI & MPM & AIH & FLA & CLI & ILS & PLA & RCC & ESR \\
\hline Teacher A & $\sqrt{ }$ & $\sqrt{ }$ & $\times$ & $\times$ & $\times$ & $\sqrt{ }$ & $\times$ & $\sqrt{ }$ & $\times$ & $\times$ \\
\hline Teacher B & $\sqrt{ }$ & $\sqrt{ }$ & $\times$ & $\times$ & $\times$ & $\sqrt{ }$ & $\times$ & $\sqrt{ }$ & $\times$ & $\times$
\end{tabular}

Key: $\sqrt{ }$ Observed trace of using the strategy; $\times$ Not observed.

\subsubsection{Teacher Beliefs Concerning Postmethod}

The interviews consisting of the semi-structured questions are within the theoretical framework of postmethod proposed by Kumaravadivelu. The interviews involve four aspects: teacher's autonomy, theory vs. practice, particular teaching, and macrostrategies.

(1) Teacher's autonomy. Both teachers tend not to follow a regular and fixed teaching method, and claim how their English teachers teach them will influence their present teaching, and follow the textbook without any adaptation.

Teacher A: I know a little about Task-based Language Teaching Approach that I have heard much. I have mainly learned the methods from the researchers and excellent English teachers. The methods can be used only after modification. Our former English teachers have the potential to affect our present language teaching. I seldom adapt the textbook.

Teacher B: I utilize the teaching methods learned from university and other teachers. The teaching approaches created by theorists are too ideal to be used in a particular classroom. How my teachers teach me in schools has great influence on my present teaching. But the most influential one is my junior middle school English teacher. I always follow the textbook.

(2) Theory and practice. Both Teacher A and B consider that theory is very important, it can guide practice. Besides, they do not agree with the belief that one establishes his/her own methods based on his/her own teaching experiences.

Teacher A: Actually, we may use the methods established by the theorists unconsciously. While teaching, 
we will think what methods are more effective. I have my own teaching model to which some good items will be added after listening to other teachers' lessons. The relationship between theory and practice is interactive. Practice should be guided by theory.

Teacher B: I think theory is very important, as it can be used to instruct practice. Anyway, theory should be modified in the process of practice. I never think about establishing my teaching methods from my teaching experiences.

(3) Particular teaching. In response to the question: "Will you teach the lesson differently to other students?" Teacher A's statements reflect that the teaching procedure is always fixed, except for only partial changes. From teacher B's statements, she holds the belief that the teaching contents serve the exams.

Teacher A: The class you observed is Class 1 . When I teach the same unit to Class 5 which is at a higher level, I still teach them in the same way. The big difference is that the teaching schedule is different. However, if I teach the students from the countryside, I may present some animals (such as big ducks, small ducks) to teach the comparative degree.

Teacher B: When I teach my students, I always spend 5-6 minutes reviewing the content of the previous lesson at the beginning of the class. If the students are at a higher level, I probably review, or I probably do not review. If the teaching targets are at a lower level, I will expand fewer contents. On the contrary, if the students are at a higher level, I will add more contents.

(4) Macrostrategies. Kumaravadivelu raises ten macrostrategies: MLO, FNI, MPM, AIH, FLA, CLI, ILS, PLA, RCC, and ESR. These interview questions directly address the ten macrostrategies.

In response to the questions: "What is learning opportunity? How do you maximize the learning opportunity?" Both teachers think the dimension of maximizing learning opportunity is the classroom. Teacher A regards teacher as the main character who creates "learning opportunity". Actually, learning opportunity is more concerned about learners themselves. Teacher B has a basic understanding about learning opportunity.

Teacher A: I think learning opportunity is more concerned about teacher himself/herself. To maximize the learning opportunity, teacher should guide students to learn some learning strategies. Anyway, the learning in the classroom should be emphasized.

Teacher B: I don't know what learning opportunity is. In my opinion, the utilization of the errors/mistakes the students make can be considered as a learning opportunity. Anyway, classroom is very important to learning opportunity.

In response to the questions: "How do you understand interaction?" and "How to facilitate negotiated interaction?" Both teachers have their own understanding of interaction, and their ways to facilitate negotiated interaction.

Teacher A: That is the degree that the students can finish the task. I often ask "do you understand?" to check whether they follow me.

Teacher B: I think interaction is the mutual understanding between teacher and learner. If the students do not understand, I will translate.

In response to the question: “There is usually a gap between teachers' and learners' intentions. What causes this perceptual intention?" From teacher A's perspective, the linguistic and cognitive sources cause perceptual intention. Teacher B only considers the linguistic sources which causes the perceptual intention.

Teacher A: We should ask ourselves "Is the language point very difficult?" and "Does the teacher teach improperly?" Besides, the students' thinking is different from the teacher's.

Teacher B: Maybe the teacher sets higher teaching aims, overestimating the students' ability.

The question: "How to do you teach grammar?" is intended to assess teachers' response to "Activating Intuitive Heuristics (AIH)". Teacher A has similar belief, but no corresponding teaching behaviors are observed. Teacher $\mathrm{B}$ tends to use "deductive" more than "inductive".

Teacher A: Grammar is not emphasized. I usually teach grammar in some contexts. And I also ask the students to induce the rules from some sentences.

Teacher B: First, I will guide the students to find the rule(s) from one or more sentences. Then, I will give them a lot of examples to illustrate my point.

When the teachers are asked to respond to the question: "How to foster students' language awareness?" They've 
a literal understanding towards language awareness.

Teacher A: Listen more and imitate the native speakers.

Teacher B: I let the students experience the beauty of English language.

When asked about the strategy "contextualizing linguistic input (CLP), the two teachers are opposite to each other. Teacher B has a deeper understanding of this strategy than Teacher A. However, Teacher A is better at using this strategy in the class.

Teacher A: I think context is the setting where the topic emerges. And I like to teach the language points in contexts.

Teacher B: I think context is the time, the place, the setting of the story. Intonation can still reflect different contexts. However, it is hard for me to contextualize linguistic input.

The question "Will you integrate the four language skills in one lesson?" is intended to assess teachers' response to the strategy "Integrating Language Skills (ILS)". Both teachers seem not to have such a belief in their minds.

Teacher A: I never have a lesson involved all the four language skills.

Teacher B: In my reading class, I often integrated it into listening and speaking. I seldom have the four language skills practiced in one lesson.

When asked the questions: "What is learner autonomy?" and "How to promote learner autonomy?", Teacher A understands learner autonomy literally. Teacher B seems to have basic knowledge of learner autonomy, but she has not related knowledge about learning strategy.

Teacher A: The students find the problems by themselves. I seldom train students some learning strategies.

Teacher B: In my opinion, learner autonomy is that the students should know what they need and how to get what they need. For example, if one's reading is bad, he/she can do more reading exercises.

When concerning about raising cultural consciousness, Teacher B puts more emphasis on.

Teacher A: I do not have a regular lesson to raise cultural consciousness. I am the cultural informant, not the learners.

Teacher B: Besides the reading of the textbook, we have another specific reading class every week. In this class, we often raise cultural consciousness. Both the teacher and students are cultural informants. That depends on who is familiar with related cultures.

On ensuring social relevance, both Teacher A and B seldom notice.

Teacher A: At my first year of teaching, I like to read some journals such as "Chinese Culture" and set something as examples when teaching English. But now, since I am under great pressure, I seldom do as I did before.

Teacher B: The education departments have great influence on the teaching beliefs which I seldom follow. I do not notice the influence of economy, politics on English teaching.

\subsubsection{Teaching Practices and Teacher Beliefs}

Teachers' beliefs and their teaching practices are interactive and closely related. Any adoption of a teacher's methods is largely hidden behind his beliefs. However, you may wonder whether the subjects' beliefs are consistent with their practices.

First, Teacher A's and B's beliefs about macro-strategies are divergent. Table 2 indicates the beliefs about related strategies derived from their interviews. Teacher A holds the views about FNI, MPM, AIH, CLI and RCC, while Teacher B holds the views about MLO, FNI, MPM, CLI, PLA and RCC. The same views they hold are FNI, MPM, CLI and RCC.

Table 2. The strategies derived from the interviews

\begin{tabular}{lllllllllll}
\hline & MLO & FNI & MPM & AIH & FLA & CLI & ILS & PLA & RCC & ESR \\
\hline Teacher A & 0 & 2 & 3 & 2 & 0 & 2 & 0 & 0 & 2 & 0 \\
\hline Teacher B & 2 & 2 & 2 & 0 & 0 & 3 & 0 & 2 & 3 & 0 \\
\hline
\end{tabular}

Second, Teacher A's and B's practices about macro-strategies are convergent. Table 3 shows the strategies the 
two teachers use in their classrooms, they mainly use MLO, FNI, CLI and PLA.

Table 3. The strategies reflected from teachers' practices

\begin{tabular}{lllllllllll}
\hline & MLO & FNI & MPM & AIH & FLA & CLI & ILS & PLA & RCC & ESR \\
\hline Teacher A & 2 & 3 & 0 & 0 & 0 & 3 & 0 & 2 & 0 & 0 \\
\hline Teacher B & 2 & 3 & 0 & 0 & 0 & 2 & 0 & 1 & 0 & 0 \\
\hline
\end{tabular}

Comparing the above tables, we know that novice teachers' teaching practices and teacher beliefs are generally divergent. For example, Teacher A holds views about MPM, but it can be found in practices. Teacher B holds views about RCC, but she didn't use such strategies in practices.

Are the strategies the teachers use/know the same as the strategies Kumaravadivelu proposes? Now, the author uses "the rating scale of teaching strategy" to indicate the similarity. For example, if the teacher does not know/use "AIH", the rating is 0 . If the teacher knows/uses CLI which is quite similar to CLI proposes by KUMA, the rating is 4. Based on the interview, Teacher A knows something about MLO, but it is not completely consistent with MLO proposed by Kumaravadivelum, and the degree of similarity is 2 (See Table 2). The observed teaching practices show Teacher B uses MPM in his classroom, but it is not completely the same to MPM put forward by Kumaravadivelum, and the degree of similarity is 3 (See Table 3). The findings reveal that teachers' most practices do not match their stated beliefs, and theory is seriously separated from practice.

\section{Implications for EFL Teaching}

In this study, we observed two novice teachers' four lessons of a whole unit and had an interview respectively. Although the two novice teachers only represent themselves, their situations revealed in the research may represent those of some teachers at the same level. This section will explore the implications for EFL teaching in Chinese junior middle school based on the research results from the perspective of postmethod.

\subsection{Raising Postmethod Consciousness}

During the research, we find that teachers lack the knowledge of postmethod and they just implement some of the macrostrategies unconsciously in their classrooms. To merge the postmethod beliefs into lessons autonomously, the first most important step is to be aware of putting the beliefs into the lessons. If the teachers know the beliefs and use them consciously in their classrooms, the teaching efficiency will be improved. Meanwhile, the gap between theory and practice will be decreased.

\subsection{Designing Lessons with Postmethod Beliefs}

To combine postmethod with lessons, first, we should keep in mind that learner-centered teaching is the foundation for implementing postmethod beliefs. However, we find that the students are not the centers in the observed classes. Teachers' explanations always dominate the observed class. So the teachers should shift from teacher-centered to learner-centered, and they can play the roles of organizers, controllers, assessor, prompters, participants and source of information (Wang Duqin, 2002).

Teacher/learner autonomy is emphasized in postmethod theory. But the investigation record shows that the observed teachers see the textbook as the Bible, and the classrooms are always considered to be the only learning places. Neither the learners nor the teacher has autonomy. As autonomous teachers, they can: (1) redevelop the textbooks by the ways of deleting, reordering, replacing, modifying the contents or justifying the teaching methods; (2) construct EFL learning environments in and out of classrooms; (3) promote learners' language awareness and cross-cultural awareness. Meanwhile, teachers should make students become autonomous learners.

Postmethod is not a specific teaching method or approach, it is a kind of pedagogy. Unlike method/approach, postmethod does not prescribe what and how teachers should do in the classroom, instead of giving teachers classroom guidelines macroscopically. More importantly, teachers can use the teaching beliefs to create teaching activities being suitable for specific teaching situations. For example, under the guideline of the macro-strategies "Activating Intuitive Heuristics", "Contextualized Linguistic Input" and "Integrate Language Skills", teachers can design the following activities while teaching attributive clause. First, show the students the picture of Harry Potter and say "Harry Potter is brave", "Harry Potter is a boy", "Harry Potter is a boy who is brave". Next, show other pictures to introduce some sentences as above. Then, discuss and find out the rules of the sentences. Later, create some situations in which students practice attributive clause. At last, the students are required to write about their English teacher with at least 5 attributive clauses. 


\subsection{Building Teachers' Own Theories}

While utilizing the postmethod beliefs in the classroom, the teachers can combine them with critical reflection during/after the class so as to build their own teaching theories. Critical reflection implies that teachers should be aware of their belief systems and constantly how far their actions reflect those beliefs or are in keeping with them (Williams and Burden, 2000). Critical reflection also implies that teachers should be reflective practitioners. As reflective practitioners, they can ensure the teaching quality by reflecting on what teaching procedures go wrong and why, what teaching procedures go well and why. More importantly, they should consider what techniques they can use in further teaching. Thereby, they can use teaching methods/strategies consciously. Critical reflection is an effective way to build teachers' own beliefs about method.

Actually, it is difficult for teachers to implement postmethod beliefs on their own. So, university researchers can give EFL teachers some necessary training.

\section{Conclusion}

Postmethod provides another alternative to method. It also empowers the EFL teachers to theorize from their practice, and to be more autonomous. This research offers teachers the way to implement postmethod. Based on the theory of postmethod, the author has conducted a case study. Although it reveals the teachers' beliefs about postmethod, and their actual adoption of postmethod in the classroom, it still has its limitations. First, the sampling is limited, that is to say, the size of sampling is small. Actually, the subjects only represent themselves, although their situations revealed in the research may represent those of some teachers at the same level. Second, the time limitation may constrain the collected data. The researcher had only one-time interview which just lasted 40-50 minutes.

\section{Acknowledgements}

The author would like to thank the Editor and the anonymous referees for their valuable and helpful suggestions.

\section{References}

Adamson, B. (2004). Fashions in language teaching methodology. In A. Davies and Elder (Eds.), The Handbook of Applied Linguistics. Maldon, Mass: Blackwell.

Allwright, R. L. (1994). Teachers as researchers: Un-mixing the metaphor? TESOL Matters, 11(12), 17.

Arikan, Arda. (2006). Postmethod Condition and its Implications for English Language Teacher Education. Journal of Language and Linguistic Studies, 2(1), 1-11.

Bell, M. D. (2003). Method and Postmethod: Are They Really So Incompatible?. TESOL Quarterly, 37(2), 325-336. http://dx.doi.org/10.2307/3588507

Brown, H. D. (2002). English Language Teaching in the Post-methods Era: Toward Better Diagnosis, Treatment, and Assessment. In Richards, J. C. et al (Eds.), Methodology in Language Teaching. Cambridge: Cambridge University Press.

Broudy, Ismail, etc. (2008). A Paradigm Shift Away from Method-Wise Teaching to Strategy-wise Teaching: Reconstructive Strategy Versus Communicative Strategy. The Social Sciences, 3(8), 631-647. http://dx.doi.org/sscience.2008.631.647

Cohen, L., \& L, Manion. (1989). Research Methods in Education. London: Routledge.

Kumaravadivelu, B. (1994). The postmethod condition: (e) merging strategies for second/foreign language teaching. TESOL Quarterly, 28(1), 27-48. http://dx.doi.org/10.2307/3587197

Kumaravadivelu, B. (1999). Theorising Practice, Practising Theory: The Role of Critical Classroom Observation. In H. Trappes-Lomax, \& I. McGrath (Eds.), Theory in Language Teacher Education. London: Longman.

Kumaravadivelu, B. (2001). Toward a Postmethod Pedagogy. TESOL Quarterly, 35(4), 537-560. http://dx.doi.org/10.2307/3588427

Kumaravadivelu, B. (2003). A Postmethod Perspective on English Language Teaching. World Englishes, 22(4), 539-550. http://dx.doi.org/10.1111/j.1467-971X.2003.00317.x

Kumaravadivelu, B. (2003). Beyond Methods: Macrostrategies for Language Teaching. New Haven and London: Yale University Press.

Kumaravadivelu, B. (2006). Understanding Language Teaching: From Method to Postmethod. New York: Routledge. 
Liu Dilin. (1995). Comments on B. Kumaravadivelu's "The Postmethod Condition: (E)merging Strategies for Second/Foreign Language Teaching: 'Alternative to' or 'addition to' method? TESOL Quarterly, 29(1), 174-177. http://dx.doi.org/10.2307/3587813

Richards, J. C., \& T. S. Rodgers. (1982). Method: Approach, design and procedure. TESOL Quarterly, 16(2), 153-168. http://dx.doi.org/10.2307/3586789

Richards, J. C., \& T. S. Rodgers. (2008). Approaches and Methods in Language Teaching (2nd edition). Beijing: Foreign Language Teaching and Research Press.

Stern, H. H. (1999). Issues and Options in Language teaching. Edited by Patrick Allen \& Birgit Harley. Shanghai: Shanghai Foreign Language Education Press.

Stern, H. H. (1993). Fundamental Concepts of Language Teaching. New York: Oxford University Press.

Wang Duqin. (2000). On English Teaching Strategy. Beijing: Foreign Language Teaching and Research Press.

Wenger, Anna Frances Z. (2007). The Role of Context in Culture-Specific Care. In Peggy L. Chinn (Ed.), Anthology on caring. NY: National League for Nurses.

Williams, Marion, \& Robert L. Burden. (2000). Psychology for Language Teachers. Beijing: Foreign Language Teaching and Research Press. 